\author{
Нікішина О.В. \\ доктор економічних наук, старший науковий співробітник \\ завідувач відділу ринкових механізмів та структур \\ Інститут проблем ринку та економіко-екологічних досліджень НАН України \\ Французький бульвар, 29, м. Одеса, Україна, 65044 \\ E-mail: ksenkych@gmail.com \\ ORCID ID: 0000-0002-7172-3551
}

\title{
ДІАГНОСТИКА ЕКОЛОГІЧНОЇ ЄМНОСТІ НАЦІОНАЛЬНОЇ ЕКОНОМІКИ У СЕКТОРАЛЬНОМУ ВИМІРІ*
}

Стаття присвячена обґрунтуванню методичного забезпечення діагностики екологічної ємності (відходо- та вуглецевоємності) національної економіки у секторальному вимірі на засадах сталого розвитку. Наголошено, що даний методичний базис $є$ складовою загальної методології діагностики домінант інвестиційно-інноваційної політики природокористування національної економіки. Запропоновано систему індикаторів для діагностики екологічної ємності крізь призму Цілей і завдань сталого розвитку держави з акцентом на секторальний та інвестиційний вимір. На основі авторських методичних положень проведено кількісну та експертну оцінку відходо- та вуглецевоємності економіки України, що дозволило встановити сучасні тенденції та проблеми зниження екодеструктивного впливу секторів на природне середовище. Проведено порівняльний аналіз відходоємності валової доданої вартості різних секторів економіки, встановлено взаємовплив інвестиційного потенціалу на динаміку показників екоємності національної економіки. На підставі результатів діагностики обґрунтовано головні напрями і шляхи зменшення екологічної ємності вітчизняної економіки в координатах сталого розвитку.

Ключові слова: Цілі сталого розвитку, діагностика, відходоємність, вуглецевоємність, сектори економіки, валова додана вартість, інвестиції.

This work is licensed under a Creative Commons Attribution 4.0 International License http://creativecommons.org/licenses/by/4.0/

Постановка проблеми та її зв'язок з важливими науковими та практичними завданнями. У сучасних умовах зростає вплив аналітичної інформації на ефективність управлінських рішень органів влади різних рівнів, що актуалізує завдання вдосконалення інформаційно-методичного забезпечення для оцінки результативності екологічної політики та моніторингу впровадження Цілей сталого розвитку (далі - ЦСР) в Україні. Нині відбувається перегляд деяких традиційних підходів та методик з урахуванням вимог сучасних трансформацій, передусім інституціоналізації процесу сталого розвитку відповідно до Указу Президента №722/2019 від 30.09.2019 р. [1].

Виникають нові аналітичні завдання, такі як моніторинг трендів сталого розвитку на державному, регіональному та локальному рівні, оцінка впливу екоінвестицій й інновацій на стале використання природно-ресурсного потенціалу, екологічну ємність національної економіки тощо. Відтак, постає об'єктивна необхідність у діагностиці інвестиційноінноваційної політики природокористування, невід'ємною складовою якої є діагностика екологічної ємності (відходо- та вуглецевоємності) національної економіки на засадах сталого розвитку. Актуальність дослідження обумовлена необхідністю розробки методичного базису такої діагностики, тому що це підгрунтя $\epsilon$ науковою основою для впровадження адаптивних механізмів і заходів стимулювання раціонального природокористування національної економіки.

Аналіз останніх публікацій по проблемі. Методологічне забезпечення процесів сталого розвитку та «зеленої» трансформації економічної системи на різних рівнях $є$ предметом активного наукового пошуку. Методичний базис моніторингу ЦСР, адаптованих до України, розроблено в Національній доповіді Міністерства економічного розвитку і торгівлі України [2]. Методичні рекомендації до оцінки «зеленої» трансформації економіки держави на базі європейських індикаторів запропоновані Л. Мусіною та T. Квашою [3]. Низку методичних положень і рекомендацій щодо оцінки домінант інвестиційноінноваційної політики природокористування в державному та регіональному вимірі розроблено фахівцями Інституту проблем ринку та економіко-екологічних досліджень НАН України $[4,5,6]$. Питання уніфікації нефінансової звітності підприємств та ії̈ узгодження

* Публікацію підготовлено в межах НДР «Домінанти інвестиційно-інноваційної політики природокористування національної економіки» за рахунок коштів бюджетної програми «Підтримка розвитку пріоритетних напрямів наукових досліджень» (КПКВК 6541230). 
iз макроіндикаторами ЦСР грунтовно досліджено Я. Олійник та М. Кучерявою [7].

Існуючі методичні підходи та рекомендації передбачають діагностику різних напрямів сталого розвитку на державному, регіональному та локальному рівні, водночас поза увагою науковців залишилося питання діагностики ЦСР у розрізі секторів економіки. Секторальний вимір сталого розвитку формує додаткову аналітичну базу для диференціації механізмів раціонального природокористування за певними секторами з урахуванням їх специфіки, для здійснення міжсекторального порівняльного аналізу індикаторів сталого розвитку, значно розширюючи межі аналітичного дослідження.

Формулювання цілей дослідження. Мета статті - розробка методичного забезпечення та проведення діагностики екологічної ємності економіки України у секторальному вимірі на засадах сталого розвитку, встановлення тенденцій і проблем скорочення відходо- та вуглецевоємності секторів націона- льної економіки, шляхів їх подолання та інвестиційного забезпечення в умовах кризи.

Виклад основних результатів та їх обгрунтування. Система індикаторів для діагностики екоємності національної економіки на засадах сталого розвитку наведена в таблиці 1. Група авторських показників, інтегрована в дану систему, дозволяє детально проаналізувати динаміку змін обсягів утворених відходів за категоріями матеріалів та секторами економіки, утилізованих відходів, видалених у спеціально відведених місцях чи об'єктах, накопичених протягом експлуатації у місцях видалення. Секторальний вимір відходоємності характеризують зміни секторальної структури утворених відходів та рівні відходоємності валової доданої вартості (далі - ВДВ) секторів економіки. Також вперше розроблено індикатори, що включають інвестиційну та екологічну складові (обсяг інвестицій на поводження 3 відходами на 1 тонну утворених відходів, обсяг інвестицій на охорону атмосферного повітря на 1т викидів діоксиду вуглецю $\mathrm{CO}_{2}$ ).

Таблиця 1

Методичне забезпечення діагностики екологічної ємності національної економіки на засадах сталого розвитку*

\begin{tabular}{|c|c|}
\hline ЦСР, завдання & Ключові індикатори \\
\hline \multicolumn{2}{|r|}{ 1. ВІДХОДОСМНІСТЬ ЕКОНОМІКИ } \\
\hline $\begin{array}{c}\text { ЦСР } 12 \\
\text { «Відповідальне спожи- } \\
\text { вання та виробництво» } \\
\text { Завдання 12.4 } \\
\text { «Зменшити обсяг утво- } \\
\text { рених відходів і збільши- } \\
\text { ти обсяг їх переробки та } \\
\text { повторного використан- } \\
\text { ня на основі інновацій- } \\
\text { них технологій і вироб- } \\
\text { ництв» }\end{array}$ & $\begin{array}{l}\text { 1. Обсяг утворених відходів усіх видів економічної діяльності на одиницю } \\
\text { ВВП, кг на } 1000 \text { дол. ПКС } 2011 \text { р. } \\
\text { 2. Частка спалених та утилізованих відходів у загальному обсязі утворених } \\
\text { відходів, \% } \\
\text { 3. Продуктивність ВВП за відходами I-IV класів (у постійних цінах } 2016 \text { р.), } \\
\text { грн. / кг } \\
\text { 4. Індекс відходів I-IV класів (у т.ч. відходів I-III класів небезпеки), у \% до } \\
2015 \text { р.** } \\
\text { 5. Індекс побутових і подібних відходів на } 1 \text { особу, у \% до } 2015 \text { р.** } \\
\text { 6. Індекс утилізованих відходів I-IV класів, у \% до } 2015 \text { р** } \\
\text { 7. Індекс відходів I-IV класів, видалених у спеціально відведених місцях чи } \\
\text { об’єктах, у \% до } 2015 \text { р** } \\
\text { 8. Індекс відходів, накопичених протягом експлуатації у місцях видалення } \\
\text { відходів, у \% до } 2015 \text { р** } \\
\text { 9. Індекс утворених відходів за матеріалами, у \% до } 2015 \text { р.** }\end{array}$ \\
\hline $\begin{array}{c}\text { Секторальний вимір } \\
\text { відходоємності }\end{array}$ & $\begin{array}{l}\text { 10. Індекс утворених відходів за секторами економіки, у \% до } 2015 \text { р.** } \\
\text { 11. Зміни секторальної структури відходів порівняно з } 2015 \text { р., \% ** } \\
\text { 12. Секторальна відходоємність ВДВ, у фактичних цінах, кг / тис. грн. ** } \\
\text { 13. Індекс секторальної відходоємності ВДВ, у \% до } 2015 \text { р. }\end{array}$ \\
\hline $\begin{array}{c}\text { Інвестиційний вимір } \\
\text { відходоємності }\end{array}$ & $\begin{array}{l}\text { 14. Частка інвестицій на поводження з відходами в сукупних витратах на охо- } \\
\text { рону НПС, \% ** } \\
\text { 15. Обсяг інвестицій на поводження з відходами на 1т утворених відходів, } \\
\text { грн./т** }\end{array}$ \\
\hline \multicolumn{2}{|r|}{ 2. ВУГЛЕЦЕВОСМНІСТЬ ЕКОНОМІКИ } \\
\hline $\begin{array}{c}\text { ЦСР } 12 \\
\text { Завдання } 12.1 \\
\text { «Знизити ресурсосм- } \\
\text { ність економіки» }\end{array}$ & $\begin{array}{l}\text { 1. Вуглецевоємність ВВП (відношення обсягу викидів } \mathrm{CO}_{2} \text { від стаціонарних } \\
\text { джерел до ВВП у постійних цінах } 2010 \text { р.), \% до } 2015 \text { р. } \\
\text { 2. Вуглецева продуктивність ВВП (у постійних цінах } 2010 \text { р.), грн. / кг } \\
\text { 3. І Індекс викидів діоксиду вуглецю від стаціонарних джерел забруднення, } \\
\text { загальний і за секторами економіки у \% до } 2015 \text { р. ** } \\
\text { 4. } \text { Індекс викидів діоксиду вуглецю на } 1 \text { особу, у \% до } 2015 \text { р. ** }\end{array}$ \\
\hline $\begin{array}{c}\text { Інвестиційний вимір } \\
\text { вуглецевоємності }\end{array}$ & $\begin{array}{l}\text { 5. Частка інвестицій на охорону атмосферного повітря в сукупних витратах } \\
\text { на охорону НПС, \% ** } \\
\text { 6. Обсяг інвестицій на охорону атмосферного повітря на 1т викидів } \mathrm{CO}_{2}, \text { грн./т }\end{array}$ \\
\hline
\end{tabular}

"Розроблено автором на основі джерел $[2,3]$

*** Індикатори запропоновано автором 
Використовуючи запропоноване методичне забезпечення (див. табл. 1), проведемо діагностику екоємності національної економіки у секторальному вимірі. Головні індикатори, що характеризують відходоємність та відходопродуктивність ВВП в Україні, узагальнено в таблиці 2. У 2019 р. обсяг утворених відходів I-IV класів склав 441,52 млн. т, збільшившись порівняно з 2015 р. на 41,4 \%, передусім за рахунок відходів від добування металевих руд. При цьому обсяг утворених побутових і подібних відходів $($ далі - ППВ) досягнув 6,62 млн. т, зменшившись порівняно з базовим періодом на 2,5\%.

Таблиця 2

Динаміка індикаторів відходоємності та відходопродуктивності ВВП в Україні*

\begin{tabular}{|c|c|c|c|c|c|c|}
\hline \multirow{2}{*}{ Індикатори } & \multicolumn{6}{|c|}{ Роки } \\
\hline & 2010 & 2015 & 2016 & 2017 & 2018 & 2019 \\
\hline 1.Обсяги утворених відходів I-IV класів, тис. т & 425914 & 312268 & 295870 & 366054 & 352334 & 441517 \\
\hline$\%$ оо $2015 p$ & $X$ & 100,0 & 94,7 & 117,2 & 112,8 & 141,4 \\
\hline 2. Обсяг утворених ППВ, тис. т & 7611,6 & 6789,2 & 6946,2 & 6183,2 & 6211,2 & 6618,0 \\
\hline$\%$ до $2015 p$ & $\mathrm{X}$ & 100,0 & 102,3 & 91,1 & 91,5 & 97,5 \\
\hline $\begin{array}{l}\text { 3. Відходоємність ВВП, кг/ тис. дол. ПКС } \\
2011 \text { р. }\end{array}$ & 1186,7 & 977,4 & 904,2 & 992,6 & 1015,6 & н.Д. \\
\hline Індекс відходоємності ВВП & $\mathrm{X}$ & 100,0 & 92,5 & 101,6 & 103,9 & $\mathrm{X}$ \\
\hline $\begin{array}{l}\text { 4. Відходопродуктивність ВВП, грн./тонну (у } \\
\text { постійних цінах } 2016 \text { р.) }\end{array}$ & $\mathrm{X}$ & $\mathrm{X}$ & 343,4 & 395,3 & 406,9 & 394,2 \\
\hline Індекс відходопродуктивності ВВП & $X$ & $X$ & 100,0 & 115,1 & 102,9 & 96,9 \\
\hline $\begin{array}{l}\text { 5. Обсяг утворених побутових і подібних від- } \\
\text { ходів, кг/особу }\end{array}$ & 165,9 & 158,5 & 162,8 & 145,5 & 146,9 & 157,5 \\
\hline$\%$ до $2015 p$ & $X$ & 100,0 & 102,7 & 91,8 & 92,7 & 99,4 \\
\hline
\end{tabular}

*Розраховано автором за даними Державної служби статистики України $[8,9,10]$

У звітному році індикатор відходоємності ВВП склав 1015,7 кг / тис.дол. ПКС 2011 р., перевищивши на $6,9 \%$ цільове значення індикатора 2020 року (950 кг / тис. дол. ПКС 2011) [2, с. 93]. Індикатор продуктивності ВВП за відходами в 2019 р. склав 394,2 грн./т, зменшившись порівняно з базовим періодом на 3,1 \% (див. табл. 2). Причиною знижувального тренду даного індикатора стало випередження темпу зростання обсягів утворених відходів над темпом зростання ВВП у постійних цінах 2016 р.

У 2018 р. обсяг утворених ППВ на одну особу досягнув 157,5 кг, зменшившись порівняно 3 2015 р. на 0,6 \%. В Україні проблема управління побутовими відходами залишається однією 3 найбільш актуальних господарських і екологічних проблем. В
Україні тільки 78 \% населення забезпечено послугами 3 вивезення ППВ, що обумовлено, передусім, нерозвиненістю інфраструктури для їх переробки та утилізації [3, с. 23].

У 2019 р. обсяг утилізованих відходів I-IV класів в Україні склав 108 млн. тонн, збільшившись порівняно 32015 р. на 16,8 \%, обсяг спалених відходів - 1,06 млн. тонн, зменшившись на 6,7 \% (таблиця 3). Частка спалених та утилізованих відходів у загальному обсязі утворених відходів у звітному році досягла 24,7 \%, скоротившись порівняно з 2010 р. на $9,8 \%$. Даний індикатор не досягнув цільового значення показника 2020 р. (35\%), що є свідченням невирішеності актуальних проблем поводження з відходами в країні.

Таблиця 3

Динаміка обсягів утилізованих, спалених та накопичених відходів I-IV класів в Україні, тис. т *

\begin{tabular}{|l|c|c|c|c|c|c|}
\hline \multicolumn{2}{|c|}{ Показники } & \multicolumn{5}{c|}{ Роки } \\
\cline { 2 - 7 } & $\mathbf{2 0 1 0}$ & $\mathbf{2 0 1 5}$ & $\mathbf{2 0 1 6}$ & $\mathbf{2 0 1 7}$ & $\mathbf{2 0 1 8}$ & $\mathbf{2 0 1 9}$ \\
\hline 1. Утилізовано відходів I-IV класів & 145711 & 92464 & 84630 & 100056 & 103658 & 108024 \\
\hline$y \%$ до 2015 $p$. & $X$ & 100,0 & 91,5 & 108,2 & 112,1 & 116,8 \\
\hline 2. Спалено відходів & 1058,6 & 1134,7 & 1106,1 & 1064,3 & 1028,6 & 1059 \\
\hline$y \%$ до 2015 $p$. & $X$ & 100,0 & 97,5 & 93,8 & 90,6 & 93,3 \\
\hline $\begin{array}{l}\text { 3. Частка спалених та утилізованих } \\
\text { відходів у загальному обсязі утворе- } \\
\text { них відходів, \% }\end{array}$ & $\mathbf{3 4 , 5}$ & $\mathbf{3 0 , 0}$ & $\mathbf{2 9 , 0}$ & $\mathbf{2 7 , 6}$ & $\mathbf{2 9 , 7}$ & $\mathbf{2 4 , 7}$ \\
\hline
\end{tabular}


Продовження табл.3

\begin{tabular}{|c|c|c|c|c|c|c|}
\hline \multirow{2}{*}{ Показники } & \multicolumn{6}{|c|}{ Роки } \\
\hline & 2010 & 2015 & 2016 & 2017 & 2018 & 2019 \\
\hline $\begin{array}{l}\text { 4. Видалено у спеціально відведені } \\
\text { місця чи об'єкти }\end{array}$ & 336952,2 & 152295 & 157379 & 169802 & 169524 & 238997 \\
\hline$y \%$ до $2015 p$ & $X$ & 100,0 & 103,3 & 111,5 & 111,3 & 156,9 \\
\hline У \% до обсягів утворених відходів & 79,1 & 48,8 & 53,2 & 46,4 & 48,1 & 54,1 \\
\hline $\begin{array}{l}\text { 5. Накопичено протягом експлуатації } \\
\text { у місцях видалення відходів на кінець } \\
\text { року, млн. тонн }\end{array}$ & 13267,5 & 12506 & 12394 & 12442 & 12972 & 15399 \\
\hline$y \%$ до $2015 p$ & $X$ & 100,0 & 99,1 & 99,5 & 103,7 & 123,1 \\
\hline У розрахунку на 1 особу, т & 289,2 & 291,9 & 289,3 & 292,9 & 306,9 & 366,4 \\
\hline$y \%$ до $2015 p$. & $X$ & 100,0 & 99,1 & 100,3 & 105,1 & 125,5 \\
\hline
\end{tabular}

*Розраховано авторами за даними Державної служби статистики України [9, 10]

У спеціально відведені місця чи об'єкти було в 2019 р. видалено 239 млн. т відходів або 54,1 \% від їх загального обсягу в державі; порівняно з базовим роком обсяг таких відходів зріс на 57 \% (див. табл. 3). У звітному році було накопичено протягом експлуатації у місцях видалення 15,4 млрд. тонн відходів, що на $23,1 \%$ вище рівня 2015 р. У розрахунку на 1 особу обсяг накопичених відходів досягнув 366,4 тонн, збільшившись порівняно з 2015 р. на 25,5\%.

У секторальній структурі утворених відходів в Україні 88,5 \% припадає на добувну промисловість і розроблення кар'єрів, 3 них 83,1 \% займають відходи від добування металевих руд (таблиця 4). Друге місце посідає переробна промисловість із часткою 7 \% (з них 4,9\% займають відходи металургійного виробництва), третє - енергетичний сектор та сільське господарство із частками $1,3 \%$ та 1,5 \% відповідно. Питома вага відходів домогосподарств у звітному році досягла 1,3\%, зменшившись порівняно 3 базовим періодом на 2,6\%.

Таблиця 4

Структурно-динамічні зміни утворених відходів в Україні у секторальному вимірі*

\begin{tabular}{|c|c|c|c|c|c|c|c|c|}
\hline \multirow[b]{2}{*}{ Сектори } & \multicolumn{2}{|c|}{2015 рік } & \multirow{2}{*}{$\begin{array}{c}2016 \\
\text { рік } \\
\text { тис. т } \\
\end{array}$} & \multirow{2}{*}{$\begin{array}{c}2017 \\
\text { рік } \\
\text { тис. Т } \\
\end{array}$} & \multirow{2}{*}{$\begin{array}{l}2018 \\
\text { рік } \\
\text { тис. Т }\end{array}$} & \multicolumn{2}{|c|}{2019 рік } & \multirow{2}{*}{$\begin{array}{c}2019 \mathrm{p} . \mathrm{y} \\
\% \text { до } \\
2015 \mathrm{p} . \\
\end{array}$} \\
\hline & Тис. т & $\%$ & & & & Тис. т & $\%$ & \\
\hline $\begin{array}{l}\text { 1.Сільське, лісове та рибне } \\
\text { господарство }\end{array}$ & 8736,8 & 2,8 & 8715,5 & 6188,2 & 5968,1 & 6750,5 & 1,5 & 77,3 \\
\hline $\begin{array}{l}\text { 2.Добувна промисловість і } \\
\text { розроблення кар'єрів }\end{array}$ & 257862 & 82,6 & 237461 & 313738 & 301449 & 390564 & 88,5 & 151,5 \\
\hline $\begin{array}{l}\text { у т.ч. добування метале- } \\
\text { вих руд }\end{array}$ & 238157 & 76,3 & 222477 & 293710 & 282482 & 367084 & 83,1 & 154,1 \\
\hline $\begin{array}{l}\text { 3.Переробна промисло- } \\
\text { вість, всього, у тому числі: }\end{array}$ & 31000,5 & 9,9 & 34093,0 & 32176,7 & 31523,2 & 30751,8 & 7,0 & 99,2 \\
\hline $\begin{array}{l}\text { 3.1. Виробництво харчо- } \\
\text { вих продуктів }\end{array}$ & 4222,2 & 1,4 & 5089,8 & 6446,5 & 5818,4 & 5581,4 & 1,3 & 132,2 \\
\hline $\begin{array}{l}\text { 3.2. Металургійне виро- } \\
\text { бництво }\end{array}$ & 20726 & 6,6 & 22265 & 21980 & 21799 & 21515,3 & 4,9 & 103,8 \\
\hline $\begin{array}{l}\text { 4.Постачання електроенер- } \\
\text { гіï, газу, пари та кондиці- } \\
\text { йованого повітря }\end{array}$ & 6597,5 & 2,1 & 7511,5 & 6191,7 & 6322,7 & 5959,2 & 1,3 & 90,3 \\
\hline $\begin{array}{l}\text { 5. Водопостачання; каналі- } \\
\text { зація, поводження з відхо- } \\
\text { дами }\end{array}$ & 594,2 & 0,2 & 457,4 & 408,7 & 397,4 & 411,8 & 0,1 & 69,3 \\
\hline 6.Будівництво & 376,2 & 0,3 & 300,2 & 493,8 & 378,8 & 188,7 & 0,04 & 50,2 \\
\hline $\begin{array}{l}\text { 7.Інші види економічної } \\
\text { діяльності }\end{array}$ & 1047,2 & 1,9 & 984,6 & 998,7 & 751,3 & 994,0 & 0,2 & 94,9 \\
\hline 8.Від домогосподарств & 6053,3 & 2,8 & 6346,5 & 5858,0 & 5543,5 & 5896,7 & 1,3 & 97,4 \\
\hline
\end{tabular}

*Розраховано автором за даними Державної служби статистики України [9, 10]. 
За 2015-2019 рр. найбільш вагомою структурною зміною стало зростання частки відходів від добування металевих руд на 6,9 \% та скорочення питомої ваги переробної промисловості та сільського господарства на 3 \% та 1,3 \% відповідно. За досліджуваний період обсяги відходів добувної промисловості зросли на 51,5 \%, харчової промисловості - на $32,2 \%$ Інші сектори за обсягом утворених відходів мали знижувальний тренд (див. табл. 4). Зокрема, в сільському господарстві індикатор скоротився на 22,7 \%, в секторі будівництва - на 49,8 \%.

У країнах ЄС обсяг відходів добувної промисловості та розроблення кар'єрів є значно нижчим, ніж в Україні. Так, у 2016 р. він склав у Швеції 109,7 млн. т, Франції - 93,66 млн. т, Польщі 70,65 млн. т, Великобританії - 17,1 млн. т, Німеччині - 7,2 млн. т [3]. В Україні обсяг відходів добувної промисловості в 2016 р. досягнув 237,5 млн. т (див. табл. 4), і це є найбільшим серед європейських країн показником.

Динаміка індикатора відходоємності ВДВ секторів національної економіки, які займають вагому частку в структурі утворених відходів, представлена в таблиці 5. У 2019 р. в цілому по економіці індикатор досягнув 169,24 кг / тис. грн. (у постійних цінах 2016 р.), збільшившись порівняно з 2015 р. на 36,4 \%. У звітному році найвищий рівень секторальної відходоємності ВДВ був характерним для добувної промисловості - 3137,9 кг / тис. грн., що в 18,5 рази вище середнього значення по економіці. Найменше значення індикатора було притаманне сільському господарству - 22,65 кг / тис. грн., що більш ніж в 7 разів нижче державного рівня. Індикатор відходоємності ВДВ у переробній промисловості склав 98,6 кг / тис. грн., у секторі постачання електроенергії - 87,27 кг / тис. грн., водопостачання - на 51,56 кг / тис. грн., що нижче середнього рівня на 42, 48 і 70 \% відповідно.

Таблиця 5

Динаміка секторальної відходосмності валової доданої вартості (ВДВ) у постійних цінах 2016 р. в Україні, кг / тис. грн.*

\begin{tabular}{|l|c|c|c|c|}
\hline \multicolumn{1}{|c|}{ Показники } & \multicolumn{3}{|c|}{ Роки } \\
\cline { 2 - 5 } & $\mathbf{2 0 1 6}$ & $\mathbf{2 0 1 7}$ & $\mathbf{2 0 1 8}$ & $\mathbf{2 0 1 9}$ \\
\hline 1. Всього по економіці & $\mathbf{1 2 4 , 0 4}$ & $\mathbf{1 4 9 , 7 6}$ & $\mathbf{1 3 9 , 4 0}$ & $\mathbf{1 6 9 , 2 4}$ \\
\hline У\% до 2016 $p$. & 100,0 & 120,7 & 112,4 & 136,4 \\
\hline 2. Добувна промисловість & 1803,7 & 2537,0 & 2378,5 & $\mathbf{3 1 3 7 , 9}$ \\
\hline У\% до 2016 $p$. & 100,0 & 140,7 & 131,9 & 174,0 \\
\hline 3. Переробна промисловість & 116,97 & 105,25 & 102,00 & 98,60 \\
\hline У\% до 2016 $p$. & 100,0 & 90,0 & 87,2 & 84,3 \\
\hline 4. Постачання електроенергіі & 101,77 & 90,00 & 89,22 & 87,27 \\
\hline У\% до 2016 $p$. & 100,0 & 88,4 & 87,7 & 85,8 \\
\hline 5. Сільське господарство & 31,16 & 22,66 & 20,22 & $\mathbf{2 2 , 6 5}$ \\
\hline У\%до 2016 $p$. & 100,0 & 72,7 & 64,9 & 72,7 \\
\hline 6. Водопостачання & 53,80 & 52,30 & 51,13 & 51,56 \\
\hline У\%до 2016 $p$. & 100,0 & 97,2 & 95,0 & 95,8 \\
\hline
\end{tabular}

*Розраховано автором за даними Державної служби статистики України [8, 9, 10].

Серед секторів національної економіки зростаючий тренд відходоємності ВДВ має лише добувна промисловість (рис. 1). Індикатори інших секторів за 2016-2019 рр. мають знижувальний тренд.

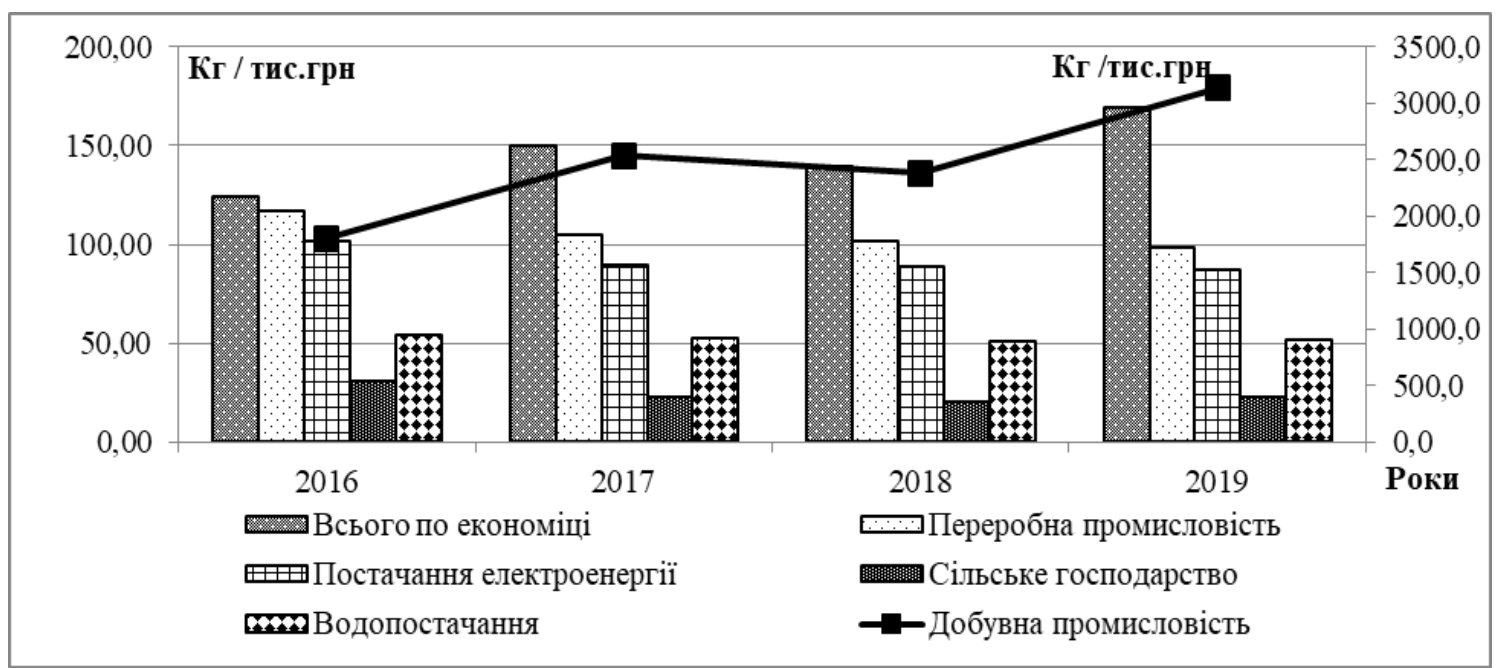

Рис. 1. Секторальна відходосмність ВДВ в Україні, кг/тис. грн.

*побудовано автором за даними таблиці 5. 
У 2019 р. загальна сума інвестицій на заходи поводження 3 відходами в Україні склала 15981,4 млн. грн., збільшившись порівняно з 2016 р. на $79 \%$, порівняно з 2018 р. - на 59,6 \% (таблиця 6). Таке істотне зростання відбулося за рахунок п'ятірного збільшення обсягів капітальних інвестицій на поводження з відходами у звітному році. Як наслідок, питома вага інвестицій на поводження з відходами в сукупних витратах на охорону НПС в Україні склала 36,54 \% в 2019 р., збільшившись порівняно 3
2016 р. на 9,1\%. У звітному році на 1 тонну утворених відходів припадало 36,2 грн. інвестицій; даний індикатор є найвищим за досліджуваний період. Однак зростання обсягів екоінвестицій на заходи поводження 3 відходами у 2019 р. супроводжувалися негативною тенденцією збільшення обсягів утворених відходів в Україні (див. табл. 2), що є свідченням відсутності позитивного зворотного зв'язку між інвестиційною політикою природокористування та станом природного середовища.

Таблиця 6

Динаміка загальних та питомих інвестицій на поводження з відходами в Україні, млн. грн.*

\begin{tabular}{|c|c|c|c|c|c|c|c|c|}
\hline \multirow{2}{*}{ Показники } & \multicolumn{6}{|c|}{ Роки } & \multicolumn{2}{|c|}{2019 р. у \% до: } \\
\hline & 2010 & 2015 & 2016 & 2017 & 2018 & 2019 & 2016 & 2018 \\
\hline $\begin{array}{l}\text { 1.Капітальні інвестиції на } \\
\text { поводження з відходами }\end{array}$ & 475,6 & 737,5 & 2208,7 & 2471,0 & 1182,1 & 5754,3 & 260,5 & y 4,9 p. \\
\hline 2.Поточні інвестиції & 2599,6 & 6801,9 & 6719,6 & 7508,2 & 8830,2 & 10227,1 & 152,2 & 115,8 \\
\hline $\begin{array}{l}\text { 3. Усього інвестиції на по- } \\
\text { водження } 3 \text { відходами }(1+2) \text {, } \\
\text { млн. грн. }\end{array}$ & 3075,2 & 7539,4 & 8928,3 & 9979,2 & 10012,3 & 15981,4 & 179,0 & 159,6 \\
\hline $\begin{array}{l}\text { 4. Частка інвестицій на по- } \\
\text { водження з відходами у су- } \\
\text { купних витратах на охорону } \\
\text { природного середовища, \% }\end{array}$ & 23,42 & 30,66 & 27,48 & 31,69 & 29,11 & 36,54 & $\mathrm{X}$ & $\mathrm{X}$ \\
\hline $\begin{array}{l}\text { 5. Обсяг інвестицій на пово- } \\
\text { дження } 3 \text { відходами на 1т } \\
\text { утворених відходів, грн./т }\end{array}$ & 7,26 & 24,14 & 30,18 & 27,26 & 28,42 & 36,20 & 119,9 & 127,4 \\
\hline
\end{tabular}

*Розраховано автором за даними Державної служби статистики України $[8,9,10]$.

**ІІндикатор запропоновано автором.

У секторальній структурі капітальних інвестицій на поводження 3 відходами в 2019 р. 81 \% припадало на сектор енергопостачання, 8,1\% - добувну промисловість і розроблення кар'єрів, 5,8 \% і 4,5\% переробну промисловість і сектор водопостачання; частка сільського господарства $є$ незначною - 0,01\% (рис. 2). Слід зазначити, що в 2018 р. структура капінвестицій на поводження 3 відходами була зовсім іншою [6, с.91].

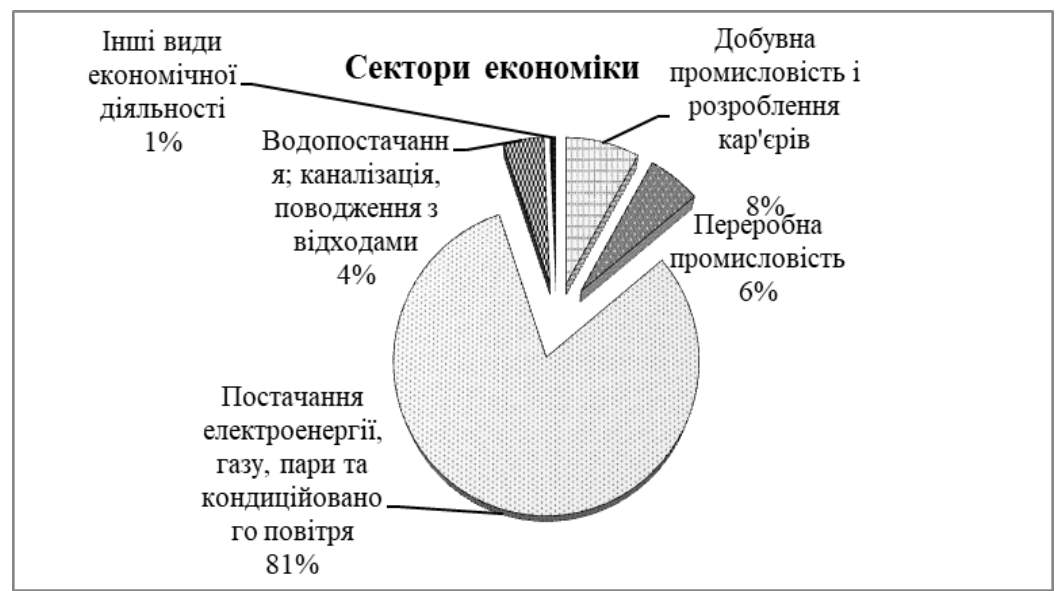

Рис. 2. Секторальна структура капітальних інвестицій на поводження з відходами в Україні в 2019 р., \%* *побудовано автором за даними Державної служби статистики України [10] 
Окрім відходоємності, другою складовою екологічної ємності економіки є вуглецевоємність. Динаміка даного індикатора дозволяє оцінити стан виконання завдання 12.1 «Знизити ресурсоємність економіки» ЦСР 12 «Відповідальне споживання й виробництво» [2, с.92]. Вуглецевоємність - це відношення обсягу викидів забруднюючих речовин в атмосферне повітря (діоксиду вуглецю $\mathrm{CO}_{2}$ ) від стаціонарних джерел у періоді, до якого проводиться розрахунок, до ВВП у тому ж періоді у цінах базисного року [11]. Головні показники, що характеризують вуглецевоємність та вуглецеву продуктивність ВВП в Україні, узагальнено в таблиці 7.

У 2019 р. викиди діоксиду вуглецю від стаці- онарних джерел забруднення склали 121283 тис. т, зменшившись порівняно з 2015 р. на 12,7\% (див. табл. 7). За період 2016-2019 рр. питома вага викидів $\mathrm{CO}_{2}$ енергетичного сектору в загальному обсязі викидів скоротилася $з$ 80,9\% до 54,2 \%, що пов'язано зі зменшенням частки сектору енергопостачання у ВВП (в постійних цінах 2016 р.) з 3,1\% до 2,6 \% відповідно. У 2019 р. індикатор вуглецевоємності ВВП (у постійних цінах 2016 р.) досягнув 46,5 кг $\mathrm{CO}_{2}$ / тис. грн., зменшившись порівняно з 2016 р. на 26,4 \%. Тенденція скорочення вуглецевоємності ВВП у 20172019 рр. обумовлена, передусім, зниженням обсягів виробництва в енергетичному секторі економіки України.

Таблиця 7

Динаміка індикаторів вуглецевоємності та вуглецевої продуктивності ВВП в Україні*

\begin{tabular}{|c|c|c|c|c|c|c|}
\hline \multirow{2}{*}{ Індикатори } & \multicolumn{6}{|c|}{ Роки } \\
\hline & 2010 & 2015 & 2016 & 2017 & 2018 & 2019 \\
\hline $\begin{array}{l}\text { 1.Викиди діоксиду вуглецю від стаціонарних } \\
\text { джерел забруднення, тис. т }\end{array}$ & 165042 & 138932 & 150581 & 124218 & 126378 & 121283 \\
\hline 1.1. Індекс викидів діоксиду вуглеияю, \% & $X$ & 100,0 & 108,4 & 89,4 & 91,0 & 87,3 \\
\hline 1.2.Викиди $\mathrm{CO}_{2}$ в енергетиці, тис.т. & 130328 & 106957 & 121767 & 104804 & 107900 & 65700 \\
\hline у\% до загальних викидів $\mathrm{CO}_{2}$ & 79,0 & 77,0 & 80,9 & 84,4 & 85,4 & 54,2 \\
\hline $\begin{array}{l}\text { 2. Вуглецевоємність ВВП у постійних цінах } \\
2016 \text { р., кг / тис. грн. }\end{array}$ & $X$ & $X$ & 63,1 & 50,8 & 50,0 & 46,5 \\
\hline 2.1. Індекс вуглецеевоємності ВВП, \% & $X$ & $X$ & 100,0 & 80,5 & 79,2 & 73,6 \\
\hline $\begin{array}{l}\text { 3.Вуглецева продуктивність ВВП в пост ці- } \\
\text { нах } 2016 \text { р., грн./т } \mathrm{CO}_{2}\end{array}$ & $\mathrm{X}$ & $\mathrm{X}$ & 15841,1 & 19676,6 & 19998,9 & 21510,4 \\
\hline 4. Індекс вуглецевої продуктивності ВВП, \% & $X$ & $X$ & 100,0 & 124,2 & 126,2 & 135,8 \\
\hline $\begin{array}{l}\text { 5. Вуглецева продуктивність ВВП в пост. } \\
\text { цінах } 2011 \text { р. за ПКС, дол./т } \mathrm{CO}_{2}\end{array}$ & 2174,7 & 2299,6 & 2173,0 & 2968,8 & 2745,1 & н.д. \\
\hline $\begin{array}{l}\text { 6. Обсяг викидів діоксиду вуглецю на } \\
1 \text { особу, тонн }\end{array}$ & 3,6 & 3,2 & 3,5 & 2,9 & 3,0 & 2,9 \\
\hline$y \%$ до $2015 \mathrm{p}$ & $X$ & 100,0 & 109,4 & 90,6 & 93,8 & 90,6 \\
\hline
\end{tabular}

*Розраховано автором за даними Державної служби статистики України $[8,9,10]$

У звітному році обсяг викидів діоксиду вуглецю на 1 особу склав 2,9 т, зменшившись порівняно з базовим роком на 9,4 \% (див. табл. 7). Незважаючи на знижувальний тренд загального й питомого показника викидів $\mathrm{CO}_{2}$, динаміка його змін у секторальному вимірі була досить різною (таблиця 8). У 2019 р. порівняно з 2015 р. зросли викиди діоксиду вуглецю в добувній промисловості (на 23,2 \%), транспорті та складському господарстві (на 53,1 \%), виробництві харчових продуктів (на 19,8\%). Зниження обсягів викидів $\mathrm{CO}_{2}$ у металургійному виробництві (на $20,9 \%$ ) та енергетичному секторі (на 12,4 \%) обумовили тенденцію скорочення загального показника.

Таблиця 8

Секторальний вимір структурно-динамічних змін обсягів викидів діоксиду вуглецю від стаціонарних джерел забруднення в Україні*

\begin{tabular}{|l|c|c|c|c|c|c|c|c|}
\hline \multirow{2}{*}{ Показники } & \multicolumn{2}{|c|}{$\mathbf{2 0 1 5}$ рік } & $\mathbf{2 0 1 6} \mathbf{p}$ & $\mathbf{2 0 1 7} \mathbf{p .}$ & $\mathbf{2 0 1 8} \mathbf{p .}$ & \multicolumn{2}{|c|}{$\mathbf{2 0 1 9}$ рік } & $\begin{array}{c}\mathbf{2 0 1 9} \mathbf{p . y} \\
\mathbf{\%}\end{array}$ \\
\cline { 2 - 10 } & Тис. т & $\%$ & Тис. т & Тис т & Тис. т & Тис. т & $\begin{array}{c}\% \\
\mathbf{2 0 1 5}\end{array}$ \\
\hline Всього & $\mathbf{1 3 8 9 3 2}$ & $\mathbf{1 0 0}$ & $\mathbf{1 5 0 5 8 1}$ & $\mathbf{1 2 4 2 1 8}$ & $\mathbf{1 2 6 3 7 8}$ & $\mathbf{1 2 1 2 8 3}$ & $\mathbf{1 0 0}$ & $\mathbf{8 7 , 3}$ \\
\hline $\begin{array}{l}\text { 1.Сільське, лісове та рибне } \\
\text { господарство }\end{array}$ & 1110,4 & 0,80 & 878,5 & 1099,8 & 1174 & 1162,2 & 0,96 & 104,7 \\
\hline
\end{tabular}


Продовження табл.8

\begin{tabular}{|c|c|c|c|c|c|c|c|c|}
\hline \multirow{2}{*}{ Показники } & \multicolumn{2}{|c|}{2015 рік } & \multirow{2}{*}{$\begin{array}{c}2016 \mathbf{p} \\
\text { Тис. т }\end{array}$} & \multirow{2}{*}{$\frac{2017 \text { p. }}{\text { Тис т }}$} & \multirow{2}{*}{$\begin{array}{c}2018 \text { p. } \\
\text { Тис. т }\end{array}$} & \multicolumn{2}{|c|}{2019 рік } & \multirow{2}{*}{$\begin{array}{l}2019 \text { p. } y \\
\text { \% до } \\
2015 \text { p. }\end{array}$} \\
\hline & Тис. т & $\%$ & & & & Тис. т & $\%$ & \\
\hline $\begin{array}{l}\text { 2.Добувна промисловість і } \\
\text { розроблення кар'єрів }\end{array}$ & 2519,4 & 1,81 & 2978,2 & 3365,2 & 3892,2 & 3105,0 & 2,56 & 123,2 \\
\hline $\begin{array}{l}\text { 3.Переробна промисло- } \\
\text { вість, всього }\end{array}$ & 57426,6 & 41,33 & 61083,6 & 49085,4 & 47877,4 & 48782,3 & 40,22 & 84,9 \\
\hline $\begin{array}{l}\text { 3.1.виробництво хар- } \\
\text { чових продуктів }\end{array}$ & 2005,4 & 1,44 & 2261,1 & 2809,8 & 2621,7 & 2402,4 & 1,98 & 119,8 \\
\hline $\begin{array}{l}\text { 3.2. виробництво коксу } \\
\text { та продуктів нафтопереро- } \\
\text { блення }\end{array}$ & 3034,1 & 2,18 & 3021,6 & 2892,2 & 3308,8 & 2151,9 & 1,77 & 70,9 \\
\hline $\begin{array}{l}\text { 3.3. металургійне ви- } \\
\text { робництво }\end{array}$ & 40544,5 & 29,18 & 44616,7 & 32995,7 & 31515 & 32068,9 & 26,44 & 79,1 \\
\hline $\begin{array}{l}\text { 4.Постачання електроенер- } \\
\text { гії, газу, пари та кондиці- } \\
\text { йованого повітря }\end{array}$ & 72250,6 & 52,00 & 79077 & 63865,2 & 68464 & 63274 & 52,17 & 87,6 \\
\hline $\begin{array}{l}\text { 5.Водопостачання; каналі- } \\
\text { зація, поводження з відхо- } \\
\text { дами }\end{array}$ & 213,8 & 0,15 & 238,1 & 246,7 & 141,7 & 240,7 & 0,20 & 112,6 \\
\hline 6. Будівництво & 467,7 & 0,34 & 122,7 & 52,8 & 57,0 & 38,0 & 0,03 & 8,1 \\
\hline $\begin{array}{l}\text { 7.Транспорт, складське } \\
\text { господарство }\end{array}$ & 2419,1 & 1,74 & 3681,9 & 4393,3 & 3749,2 & 3703,9 & 3,05 & 153,1 \\
\hline $\begin{array}{l}\text { 8.Інші види економічної } \\
\text { діяльності }\end{array}$ & 2524,5 & 1,82 & 2521 & 2109,5 & 1022,8 & 976,8 & 0,81 & 38,7 \\
\hline
\end{tabular}

*Розраховано автором за даними Державної служби статистики України $[9,10]$

В Україні у секторальній структурі викидів діоксиду вуглецю від стаціонарних джерел забруднення домінують два сектори: переробна промисловість із часткою 40,2 \% (у т.ч. металургійне виробництво 26,4 \%) та енергетичний сектор із часткою $52,2 \%$ (див. табл. 8). Питома вага інших секторів національної економіки є незначною і складає 2,6 \% для добувної промисловості, 3,1 \% - для транспорту, 1 \% - для сільського господарства. За 2015-2019 рр. найбільш вагомою структурною зміною стало скорочення частки переробної промисловості на $1,1 \%$, передусім за рахунок металургійного виробництва (на
2,7\%), та зростання питомої ваги транспорту на $1,3 \%$.

У 2019 р. обсяг інвестицій на охорону атмосферного повітря і проблеми зміни клімату в Україні склав 7,2 млрд. грн., збільшившись порівняно 3 2015 р. в 2,5 рази, порівняно з 2018 р. - на 13,1\% (таблиця 9). Динаміка змін обсягів поточних і капітальних інвестицій за даним видом природоохоронних заходів має стабільно зростаючий тренд. Як наслідок, частка інвестицій на охорону атмосферного повітря у сукупних витратах на охорону НПС зросла $311,97 \%$ в 2015 р. до $16,56 \%$ в 2019 p.

Таблиця 9

Динаміка загальних та питомих інвестицій на охорону атмосферного повітря і проблеми зміни клімату в Україні, млн. грн.*

\begin{tabular}{|l|c|c|c|c|c|c|c|c|}
\hline \multirow{2}{*}{\multicolumn{1}{|c|}{ Показники }} & \multicolumn{9}{c|}{ Роки } & \multicolumn{2}{c|}{$\mathbf{2 0 1 9}$ р. у \% до: } \\
\cline { 2 - 10 } & $\mathbf{2 0 1 0}$ & $\mathbf{2 0 1 5}$ & $\mathbf{2 0 1 6}$ & $\mathbf{2 0 1 7}$ & $\mathbf{2 0 1 8}$ & $\mathbf{2 0 1 9}$ & $\mathbf{2 0 1 5 p .}$ & $\mathbf{2 0 1 8 p .}$ \\
\hline 1.Капітальні інвестиції & 1139,9 & 1422,9 & 2502,8 & 2608,1 & 3505,9 & 4276,8 & 300,6 & 122,0 \\
\hline 2.Поточні інвестиції & 1314,8 & 1519,8 & 1760,6 & 2104,3 & 2897,7 & 2963,9 & 195,0 & 102,3 \\
\hline $\begin{array}{l}\text { 3. Усього інвестиції на } \\
\text { охорону атмосферного } \\
\text { повітря (1+2) }\end{array}$ & 2454,7 & 2942,7 & 4263,4 & 4712,4 & 6403,6 & 7240,7 & 246,1 & 113,1 \\
\hline $\begin{array}{l}\text { 4. Частка інвестицій на } \\
\text { охорону атмосферного } \\
\begin{array}{l}\text { повітря у сукупних витра- } \\
\text { тах на охорону НПС, \% }\end{array}\end{array}$ & 18,70 & 11,97 & 13,12 & 14,96 & 18,62 & 16,56 & $X$ & $X$ \\
\hline
\end{tabular}


Продовження табл.9

\begin{tabular}{|l|c|c|c|c|c|c|c|c|}
\hline \multirow{2}{*}{ Показники } & \multicolumn{3}{c|}{ Роки } & \multicolumn{2}{c|}{ 2019 р. у \% до: } \\
\cline { 2 - 9 } & $\mathbf{2 0 1 0}$ & $\mathbf{2 0 1 5}$ & $\mathbf{2 0 1 6}$ & $\mathbf{2 0 1 7}$ & $\mathbf{2 0 1 8}$ & $\mathbf{2 0 1 9}$ & $\mathbf{2 0 1 5 p .}$ & $\mathbf{2 0 1 8 p .}$ \\
\hline $\begin{array}{l}\text { 5. Інвестиції на охорону } \\
\text { атмосферного повітря на 1 } \\
\begin{array}{l}\text { т викидів СО 2 зі стаціона- } \\
\text { рних джерел забруднення, } \\
\text { грн./т* }\end{array}\end{array}$ & 14,87 & 21,18 & 28,31 & 37,94 & 50,67 & 59,70 & 281,9 & 117,8 \\
\hline
\end{tabular}

*Розраховано автором за даними Державної служби статистики України $[8,9,10]$

** Індикатор запропоновано автором.

Внаслідок вищих темпів приросту екоінвестицій порівняно 3 темпами зростання (скорочення) обсягів викидів діоксиду вуглецю, динаміка індикатора інвестицій на охорону атмосферного повітря на 1 т. викидів $\mathrm{CO}_{2}$ зі стаціонарних джерел забруднення $\epsilon$ зростаючою (див. табл. 9). У звітному році його рівень досягнув 59,7 грн. / т, збільшившись порівняно 3 2015 р. в 2,8 рази. Тенденція до зростання обсягів інвестування охорони атмосферного повітря і проблеми зміни клімату свідчить про пріоритетність даних заходів та $€$ вагомим чинником скорочення викидів діоксиду вуглецю в 2017-2019рр. (див. табл. 7).
У секторальній структурі капітальних інвестицій на охорону атмосферного повітря в 2019 р. $82 \%$ припадало на переробну промисловість, у т.ч. $71,5 \%$ - металургійне виробництво, $13 \%$ - сектор енергопостачання, $4 \%$ - добувну промисловість і розроблення кар'єрів, $1 \%$ - транспорт і складське господарство (рис. 3). У 2019 р. відбулися структурні зміни в напрямі зростання частки переробної промисловості на 3,4 \% порівняно з 2018 р. на фоні зниження питомої ваги секторів енергетики та транспорту на $1,4 \%$ та 2,6 \% відповідно. Частка сільського господарства $є$ незначною і складає $0,03 \%$.

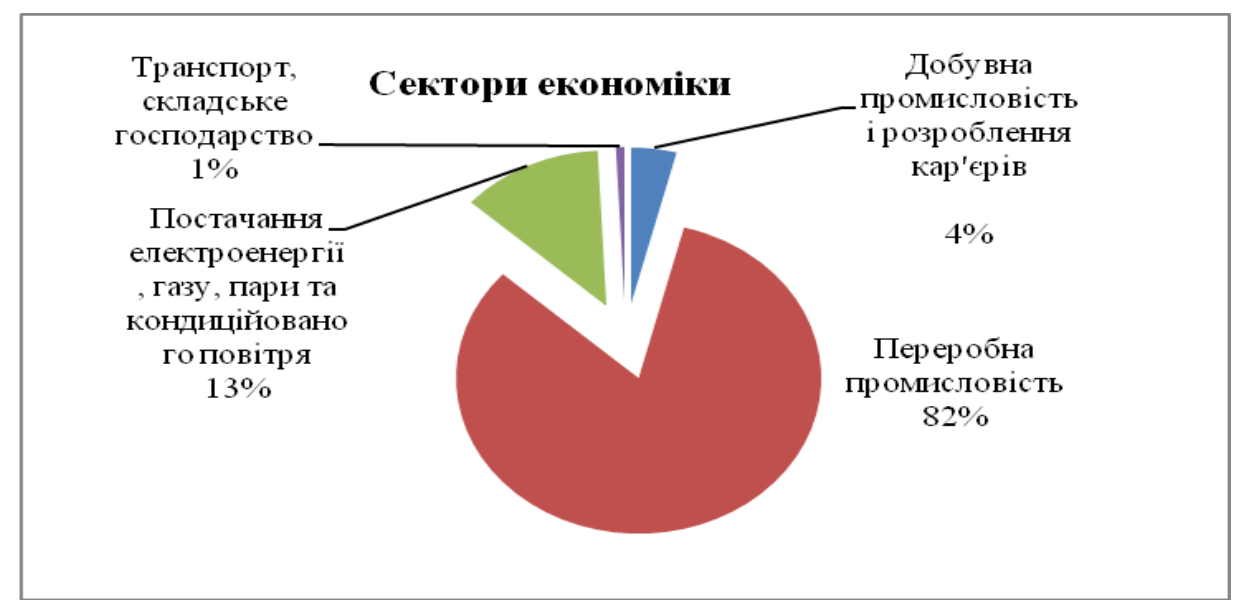

Рис. 3. Секторальна структура капітальних інвестицій на охорону атмосферного повітря і проблем зміни клімату в Україні в 2019 році, \%*

*побудовано автором за даними Державної служби статистики України [10]

У 2019 р. сума інвестицій на впровадження інтегрованих технологій у сфері охорони атмосферного повітря й проблеми зміни клімату склала 583,6 млн. грн. або 13,6 \% від капітальних інвестицій. Обсяги фінансування НДР за напрямом охорони атмосферного повітря є третіми за величиною і склали в 2019 р. 18,2 млн. грн. або 14,3 \% від загальної суми інвестування НДР природоохоронного спрямування в країні, тоді як частка НДР у сфері поводження з відходами всього 0,8\% (1 млн. грн.) [9]. Загалом інноваційний процес в сфері охорони атмосферного повітря значно краще забезпечений інвестиційними ресурсами, ніж сфера поводження з відходами.

У 2019 р. в структурі загальних капітальних інвестицій питома вага заходу охорони атмосферного повітря й проблеми зміни клімату склала 26,3%, по- сівши II місце, у структурі поточних екоінвестицій 10,8 \% (III місце). Відтак даний природоохоронний напрям достатньо забезпечений інвестиціями [9]. Індикатор вуглецевоємності ВВП у 2017-2019 рр. не тільки досягнув цільового значення показника 2020 р., а й покращив його (див. табл. 7). Водночас за групою показників «Зміна клімату та енергетика», яка $\epsilon$ складовою Індексу економічної ефективності 2018 р., Україна отримала низьку оцінку (37,59 бали), посівши у рейтингу зі 180 країн 143 сходинку. За динамікою інтенсивності викидів $\mathrm{CO}_{2}$ на одиницю ВВП Україна зайняла 134 місце [12]. Враховуючи результат міждержавних порівнянь, доцільним $є$ впровадження інноваційних заходів щодо охорони атмосферного повітря на базі світових практик. 
Для інтегральної оцінки екоємності національної економіки крізь призму впровадження Цілей сталого розвитку використаємо метод експертних оцінок. Для експертної оцінки використаємо інтервальну шкалу, що включає 5 типів оцінки [6, с.117]: (1) дуже низька - 0-0,20 бали; (2) низька - 0,21-0,35 балів; (3) середня - 0,36-0,65 бали; (4) висока середня - 0,66-0,80 бали; (5) висока - 0,81-1,00 бали. За такого способу нормування рівень екологічної ємності економіки набуває значення від 0 до 1, при цьому чим він $є$ ближчим до 1, тим вищий ступінь реалізації завдань сталого розвитку, і навпаки.

Таблиця 10

Результати експертної оцінки ступеню впровадження завдань ЦСР щодо зниження екологічної ємності національної економіки*

\begin{tabular}{|c|c|c|c|c|c|c|}
\hline \multirow{2}{*}{$\begin{array}{c}\text { Складові } \\
\text { екосмності }\end{array}$} & \multirow{2}{*}{ ЦСР і завдання } & \multicolumn{2}{|c|}{$\begin{array}{c}\text { Ступінь впрова- } \\
\text { дження ЦСР }\end{array}$} & \multirow{2}{*}{$\begin{array}{l}\text { Середньо- } \\
\text { зважена } \\
\text { оцінка }\end{array}$} & \multirow{2}{*}{$\begin{array}{c}\text { Коефіцієнт } \\
\text { вагомості }\end{array}$} & \multirow{2}{*}{$\begin{array}{l}\text { Інтегра- } \\
\text { льна оцін- } \\
\text { ка }\end{array}$} \\
\hline & & $\begin{array}{l}\text { Бальна } \\
\text { оцінка }\end{array}$ & $\begin{array}{l}\text { Якісна } \\
\text { оцінка }\end{array}$ & & & \\
\hline \multirow[t]{3}{*}{$\begin{array}{l}\text { 1. Відходо- } \\
\text { ємність } \\
\text { економіки }\end{array}$} & $\begin{array}{l}\text { 1.1. ЦСР } 12 \\
\text { Завдання 12.4 } \\
\text { «Зменшити обсяг утворених } \\
\text { відходів і збільшити обсяг їх } \\
\text { переробки та повторного ви- } \\
\text { користання на основі іннова- } \\
\text { ційних технологій і вироб- } \\
\text { ництв» }\end{array}$ & 0,20 & $\begin{array}{c}\text { Дуже } \\
\text { низький }\end{array}$ & \multirow[t]{3}{*}{$\begin{array}{c}0,29 \\
\text { Низький }\end{array}$} & \multirow[t]{3}{*}{0,55} & \multirow[t]{3}{*}{0,159} \\
\hline & $\begin{array}{l}\text { 1.2. Секторальний вимір від- } \\
\text { ходоємності }\end{array}$ & 0,36 & $\begin{array}{l}\text { Серед- } \\
\text { ній }\end{array}$ & & & \\
\hline & $\begin{array}{l}1.3 \text { Інвестиційний вимір від- } \\
\text { ходоємності }\end{array}$ & 0,31 & Низький & & & \\
\hline \multirow{2}{*}{$\begin{array}{l}\text { 2. Вуглеце- } \\
\text { во-смність } \\
\text { економіки }\end{array}$} & $\begin{array}{l}\text { 2.1. ЦСР } 12 \\
\text { Завдання } 12.1 \text { «Знизити ре- } \\
\text { сурсоємність економіки» }\end{array}$ & 0,81 & Висока & \multirow{2}{*}{$\begin{array}{c}0,86 \\
\text { Високий }\end{array}$} & \multirow[t]{2}{*}{0,45} & \multirow[t]{2}{*}{$\mathbf{0 , 3 8 7}$} \\
\hline & $\begin{array}{l}\text { 2.2. Інвестиційний вимір вуг- } \\
\text { лецевоємності }\end{array}$ & 0,90 & Висока & & & \\
\hline Усього & $X$ & $\mathrm{X}$ & $\mathrm{X}$ & $X$ & 1,00 & $\begin{array}{c}\mathbf{0 , 5 4 6} \\
\text { Середній }\end{array}$ \\
\hline
\end{tabular}

"Узагальнені результати експертного опитування

На підставі результатів діагностики (див. табл. 2-6) ступінь впровадження завдань ЦСР щодо зниження відходоємності національної економіки оцінено експертами як низький $(0,29)$ (таблиця 10). При цьому найнижчий ступінь впровадження має завдання 12.4 ЦСР 12 «Зменшити обсяг утворених відходів і збільшити обсяг їх переробки та повторного використання на основі інноваційних технологій і виробництв». За результатами діагностики (див. табл. 7-9) ступінь впровадження завдань щодо зниження вуглецевоємності економіки оцінено експертами як високий $(0,86)$. Інтегральна оцінка ступеню впровадження актуалізованих завдань сталого розвитку щодо скорочення екологічної ємності національної економіки склала 0,546 бали, що відповідає середньому рівню за оціночною шкалою. При цьому найнижче значення отримала компонента щодо зниження відходоємності економіки, сигналізуючи про «вузьке» місце у процесі впровадження ЦСР 12 «Відповідальне споживання та виробництво» в Україні.

Висновки та перспективи подальших досліджень. У ході дослідження розроблено методичне забезпечення діагностики екологічної ємності національної економіки на засадах сталого розвитку з акцентом на секторальний вимір. Особливістю авторсь- кого методичного підходу є інтеграція до національної системи показників сталого розвитку низки секторальних індикаторів, які дозволяють встановити тенденції і проблеми сталого розвитку окремих секторів економіки. Використовуючи запропоновані методичні положення, проведено діагностику відходота вуглецевоємності економіки України за 20152019 рр., що дозволило визначити секторальні відмінності у досягненні завдань ЦСР 12 в умовах кризи.

На фоні загальної тенденції зростання обсягів утворених відходів в країні, позитивна тенденція скорочення їх величини була притаманна сільському господарству та сектору водопостачання, негативна добувній і харчовій промисловості, що, до речі, не пов'язано зі зростанням обсягів виробництв даних секторів. За 2017-2019 рр. індикатор відходоємності ВДВ (у постійних цінах 2016 р.) мав знижувальний тренд у більшості секторів національної економіки: аграрному, переробному, а також водо- та енергопостачання. Водночас зростаючий тренд державного індикатора відходоємності обумовлений, передусім, збільшенням обсягів утворених відходів у добувній промисловості, як головного продуцента відходів в країні (88,5 \%). 3 іншого боку, ії частка у капітальних інвестиціях на поводження 3 відходами в 2019 p. 
склала всього $8 \%$, головним інвестором був сектор енергопостачання (81\%). Відтак, виникає необхідність у зростанні екоінвестицій добувної промисловості на заходи поводження $з$ відходами, а також імплементації в Україні положень Директиви 2006/21 СС «Про управління відходами видобувної промисловості», зокрема в частині створення фондів фінансування різних природоохоронних заходів [13].

Незважаючи на $50 \%$-ве зростання інвестицій на заходи поводження з відходами у 2019 р. порівняно з 2016 р., їх обсяги за цей період зросли в 1,5 рази, а величина утилізованих і спалених відходів скоротилася з 29 \% до 24,7 \%, не досягнувши цільових орієнтирів 2020 р. Слід відзначити, що напрям охорони атмосферного повітря краще забезпечений інвестиціями, ніж сфера поводження з відходами, про що свідчать рівні відповідних індикаторів: у 2019 р. обсяг інвестицій на поводження з відходами склав 36,2 грн. / тонну, на охорону атмосферного повітря - 59,7 грн. / тонну викидів $\mathrm{CO}_{2}$ зі стаціонарних джерел забруднення. У звітному році індикатор вуглецевоємності ВВП скоротився на 26,4\% порівняно з 2016 р., у секторальній структурі викидів діоксиду вуглецю домінують енергетичний сектор (52,2\%) та переробна промисловість (40,2\%). Проведена діагностика показала, що у 2016-2019 pр. значення індикаторів, які характеризують стан виконання 1 і 4 завдань ЦСР 12, стосовно зниження відходоємності економіки є незадовільними та не відповідають цільовим оріснтирам 2020 р., стосовно вуглецевоємності - позитивними і свідчить про прогрес у досягненні ЦСР 12 в даному аспекті.

Експертна оцінка ступеню впровадження завдань сталого розвитку стосовно зниження екоємності національної економіки $є$ середньою. Головними напрямами реалізації даних завдань $є$ стимулювання реалізації інвестиційних проектів щодо впровадження сучасних технологій переробки ППВ на засадах дер- жавно-приватного партнерства; імплементація в Україні чинних директив Свросоюзу в сфері управління відходами, у т.ч. Директиви 2006/21/СС від 15.03.2006 р. [13]; запровадження моделі циркулярної економіки, що базується на відновлювальному ланцюгу «take, make, reuse» («взяти, зробити, використати повторно») та передбачає переробку й повторне використання відходів на основі інноваційних технологій. Для забезпечення подальшого прогресу в досягненні ЦСР 12 в аспекті скорочення ресурсоємності економіки доцільним є впровадження нових заходів щодо охорони атмосферного повітря на базі світових практик. Також важливою $є$ реалізація адаптивних механізмів стимулювання суб'єктів господарювання до впровадження екологічно чистих виробництв та екоінновацій у всіх секторах економіки, а також розвиток міжсекторального партнерства, що передбачено чинними інститутами [14].

Наукова новизна проведеного дослідження полягає у вдосконаленні методичного базису діагностики екологічної ємності національної економіки у секторальному вимірі на засадах сталого розвитку, розробці та апробації нових індикаторів для оцінки взаємовпливу інвестиційного потенціалу на динаміку показників екоємності (відходо- та вуглецевоємності) національної економіки. Практичне значення отриманих результатів визначається можливістю їх використання органами влади різних рівнів, ринковими суб'єктами та різними стейкхолдерами в ході діагностики сучасних тенденцій екологічної ємності секторів економіки, як аналітичного підгрунтя для прийняття виважених управлінських рішень за напрямом сталого розвитку України. Перспективи подальших досліджень полягають у розширенні методичного базису за рахунок нових індикаторів діагностики екоємності секторів економіки для впровадження системи багаторівневого моніторингу ЦСР в державі.

\section{Лiтература}

1. Про Цілі сталого розвитку України на період до 2030 року: Указ Президента України від 30 вересня 2019 р. № 722/2019. URL: https://zakon.rada.gov.ua/laws/show/722/2019 (дата звернення 22.01.2021).

2. Цілі Сталого Розвитку: Україна: Національна доповідь 2017. Київ: Міністерство економічного розвитку і торгівлі України, 2017. 176 с.

3. Доповідь про зелену трансформацію в Україні на основі показників зеленого зростання ОЕСР. Київ: Міністерство економічного розвитку і торгівлі України, 2016. 60 с.

4. Андрєєва Н.М., Тютюнник Г.О. Методичні підходи щодо визначення домінант регіональної інвестиційно-інноваційної політики природокористування: наукова доповідь. Одеса: ІПРЕЕД НАН України, 2020. $101 \mathrm{c}$.

5. Методичні рекомендації до оцінки впливу економічних показників на головні індикатори «зеленого» зростання / Буркинський Б.В., Андрєєва Н.М. та ін. Одеса: ІПРЕЕД НАН України, 2019. 45 с.

6. Буркинський Б.В., Нікішина О.В. Методичні рекомендації до комплексної оцінки домінант інвестиційно-інноваційної політики природокористування національної економіки: наукова доповідь. Одеса: ІПРЕЕД НАН України, 2020. 195 с.

7. Олійник Я.В., Кучерява М.В. Удосконалення нормативно-правового забезпечення нефінансової звітності в Україні як результат співпраці з міжнародними інституціями. Фінанси України. 2019. №11. С.31-43. doi: 10.33763/finukr2019.11.031

8. Статистичний щорічник України за 2019 рік / за ред. І.Є.Вернера. Київ: Державна служба статистики України, 2020.465 с. 
9. Довкілля України за 2019 рік: статистичний збірник / за ред. О. М. Прокопенко. Київ: Державна служба статистики України, 2020. 200 с.

10. Офіційний сайт Державної служби статистики України. URL: http:/www.ukrstat.gov.ua/ (дата звернення 22.01.2021).

11. Про затвердження Методичних рекомендацій щодо розрахунку показників ресурсоємності валового внутрішнього продукту на рівні національної економіки за основними групами ресурсів: Наказ Мінекономрозвитку від 06.06.2019 № 965. URL: https://www.me.gov.ua/Documents/Detail?lang=uk-UA\&id=a63ce9bf-5282-4fa0984a-d3efa9253300\&title=NakazMinekonomrozvitkuVid06-06-2019-965 (дата звернення 22.01.2021).

12. Позиції України в рейтингу екологічної ефективності в 2018 році. URL: http://edclub.com.ua/analityka/pozyciyi-ukrayiny-v-reytyngu-ekologichnoyi-efektyvnosti-u-2018-roci (дата звернення 22.01.2021).

13. Управління відходами та ресурсами: короткий опис директив ЄС та графіку їх реалізації. Київ: EПTICA, 2014.9 c. URL: http://www.if.gov.ua/files/uploads (дата звернення 22.01.2021).

14. Про Основні засади (стратегію) державної екологічної політики України на період до 2030 року: Закон України № 2697-VII від 28.02.2019 p. URL: https://zakon.rada.gov.ua/laws/show/2697-19\#Техt (дата звернення 22.01.2021).

Стаття надійшла 1.02.2021

Стаття прийнята до друку 15.02.2021

Nikishyna 0.

Доступно в мережі Internet 18.04.2021

Doctor of Economics, Senior Researcher

Head of Department of Market Mechanisms and Structures

Institute of Market Problems and Economic \& Ecological Research

of National Academy of Sciences of Ukraine

Frantsuzskiy boulevard, 29, Odesa, Ukraine, 65044

E-mail: ksenkych@gmail.com

ORCID ID: 0000-0002-7172-3551

\section{DIAGNOSTICS OF ECOLOGICAL CAPACITY OF THE NATIONAL ECONOMY IN THE SECTORAL DIMENSION}

The article is devoted to the substantiation of methodical support for the diagnosticis of ecological capacity (waste and carbon capacity) of the national economy in the sectoral dimension on the basis of sustainable development. It has been emphasized that this methodical basis is a component of the general methodology for diagnosing the dominants of investment and innovation policy of nature management of the national economy. A system of indicators for the diagnosticis of environmental capacity through the prism of the Goals and Objectives of Sustainable Development of the state with an emphasis on the sectoral and investment dimension has been proposed.

On the basis of the author's methodical provisions, a quantitative and expert assessment of waste and carbon capacity of the Ukrainian economy for 2015-2019 was conducted, which allowed to identify sectoral differences in achieving the objectives of the Sustainable Development Goal 12 «Responsible consumption and production». Comparative analysis of waste capacity of the gross value added of different sectors of the economy, the impact of investment potential on the dynamics of environmental capacity indices of the national economy have been conducted.

Against the background of the general trend of growth of the generated waste in Ukraine, the positive tendency of their reduction was inherent in agriculture and water supply sector, negative - in the extractive and food industries. The growing trend of the state indicator of waste capacity of gross value added is due to the increase in the volume of waste generated in the extractive industry. In the course of the research it was established that the direction of air protection is better provided with investments than the sphere of waste management. Expert assessment of the degree of implementation of sustainable development tasks in relation to reducing the environmental capacity of the national economy is average.

Based on the diagnostics results, the main directions and ways to reduce the environmental capacity of Ukraine's economy have been substantiated, in particular: (1) stimulating the implementation of investment projects for the introduction of modern technologies for household waste processing on the basis of a publicprivate partnership; (2) implementation of EU directives in the field of waste management, including Directive 2006/21/EU «On waste management of the extractive industry»; (3) introduction of new measures for air protection on the basis of world practices. Emphasis is placed on the applied value of the proposed methodical basis for the implementation of the system of multilevel monitoring of the Sustainable Development Goals in Ukraine.

Key words: Sustainable development goals, diagnostics, waste capacity, carbon capacity, sectors of the economy, gross value added, investments. 


\section{References}

1. Pro Tsili staloho rozvytku Ukrainy na period do 2030 roku: Ukaz Prezydenta Ukrainy vid 30 veresnia 2019 r. № 722/2019. (2019). Retrieved January 22, 2021, from https://zakon.rada.gov.ua/laws/show/722/2019

2. Ministerstvo ekonomichnoho rozvytku i torhivli Ukrainy. (2017). (rep.). Tsili Staloho Rozvytku. Kyiv.

3. Ministerstvo ekonomichnoho rozvytku i torhivli Ukrainy. (2016). (rep.). Dopovid pro zelenu transformatsiiu v Ukraini na osnovi pokaznykiv zelenoho zrostannia OESR. Kyiv.

4. Andrieieva, N. M., \& Tiutiunnyk, H. O. (2020). (rep.). Metodychni pidkhody shchodo vyznachennia dominant rehionalnoi investytsiino-innovatsiinoi polityky pryrodokorystuvannia. Odesa: IPREED NAN Ukrainy.

5. Burkynskyi, B. V., \& Andrieieva, N. M. (2019). Metodychni rekomendatsii do otsinky vplyvu ekonomichnykh pokaznykiv na holovni indykatory «zelenoho» zrostannia. Odesa: IPREED NAN Ukrainy.

6. Burkynskyi, B. V., \& Nikishyna, O. V. (2020). (rep.). Metodychni rekomendatsii do kompleksnoi otsinky dominant investytsiino-innovatsiinoi polityky pryrodokorystuvannia natsionalnoi ekonomiky. Odesa: IPREED NAN Ukrainy.

7. Oliinyk, Ya. V., \& Kucheriava, M. V. (2019). Udoskonalennia normatyvno-pravovoho zabezpechennia nefinansovoi zvitnosti v Ukraini yak rezultat spivpratsi z mizhnarodnymy instytutsiiamy. Finansy Ukrainy, (11), 31-43. doi: 10.33763/finukr2019.11.031

8. Verner, I. Ye. (Ed.). (2020). Statystychnyi shchorichnyk Ukrainy za 2019 rik. Kyiv: Derzhavna sluzhba statystyky Ukrainy.

9. Prokopenko O. M. (Ed.). (2020). Dovkillia Ukrainy za 2019 rik. Kyiv: Derzhavna sluzhba statystyky Ukrainy.

10. Ofitsiinyi sait Derzhavnoi sluzhby statystyky Ukrainy. Retrieved January 22, 2021, from http://www.ukrstat.gov.ua/

11. Pro zatverdzhennia Metodychnykh rekomendatsii shchodo rozrakhunku pokaznykiv resursoiemnosti valovoho vnutrishnoho produktu na rivni natsionalnoi ekonomiky za osnovnymy hrupamy resursiv: Nakaz Minekonomrozvytku vid 06.06.2019 № 965. (2019). Retrieved January 22, 2021, from https://www.me.gov.ua/Documents/Detail?lang=uk-UA\&id=a63ce9bf-5282-4fa0-984a-

d3efa9253300\&title=NakazMinekonomrozvitkuVid06-06-2019-965

12. Pozytsii Ukrainy v reitynhu ekolohichnoi efektyvnosti v 2018 rotsi. (2018). Retrieved January 22, 2021, from http://edclub.com.ua/analityka/pozyciyi-ukrayiny-v-reytyngu-ekologichnoyi-efektyvnosti-u-2018-roci

13. 13. Upravlinnia vidkhodamy ta resursamy: korotkyi opys dyrektyv YeS ta hrafiku yikh realizatsii. (2014). Kyiv: EPTISA. Retrieved January 22, 2021, from http://www.if.gov.ua/files/uploads

14. Pro Osnovni zasady (stratehiiu) derzhavnoi ekolohichnoi polityky Ukrainy na period do 2030 roku: Zakon Ukrainy № 2697-VII vid 28.02.2019 r. (2020). Retrieved January 22, 2021, from https://zakon.rada.gov.ua/laws/show/2697-19\#Text

Received 1 February 2021

Approved 15 February 2021 Available in Internet 18.04.2021

Цитування згідно ДСТУ 8302:2015

Нікішина О. В. Діагностика екологічної ємності національної економіки у секторальному вимірі // Економіка харчової промисловості. 2021. Т.13, вип. 1. С. 49-61.

Cite as APA style citation

Nikishyna, O. (2021). Diagnostics of ecological capacity of the national economy in the sectoral dimension. Food Industry Economics, 13(1), 49-61. 